
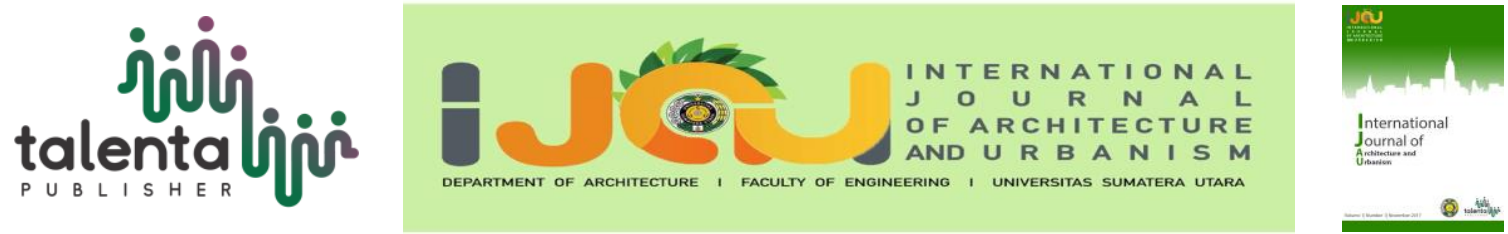

\title{
Dolok Sanggul Business Hotel (Sustainable Architecture)
}

\author{
Nurlisa Ginting ${ }^{*}$, Ivo Michael Padang ${ }^{1}$ \\ ${ }^{1}$ Department of Architecture, Universitas Sumatera Utara, Medan, Indonesia
}

\begin{abstract}
The business hotel is one of the facilities that support business work, and their activities are the reason of humans to travel some place for business in an area or urban areas. Dolok Sanggul Kab. Humbang Hasundutan is the one of area increasing their economy in every year with agriculture and hospitality sector as one of the driving axis of the economy in this area but, no one the hotel that supports business activities in around of this area. As one of the efforts undertaken to maintain the sustainability of natural, the design of Sustainable Architecture in the business hotels to be designed is very suitable theme be the reference to scheming business hotels in this area.
\end{abstract}

Keyword: business, hotel, sustainable, architecture

\section{Introduction}

The hotel sector in Indonesia is very amusing especially in cities with business activities, trade and tourism attractions are rapid. The number of hotel room supplies is expected to continue to grow rapidly. Implementation of the program Visit Indonesia by the Government also has a share in encouraging the country's hospitality business is growing every year. One of the contributing factors to the increasing need for hotels is the expansionary action of investors motivated by the potential for economic growth, business travel, and tourism in one region or city [4].

Dolok Sanggul Kab. Humbang Hasundutan is one of the areas that have improved economic improvement every year, agriculture and hospitality sector is the most dominant in influencing economic increased in the area, it will certainly have a significant effect on business people around the world to travel on business that requires progress To the provision of business facilities. Currently, there is still no amenities that support the business human around the hotel industry will be very good in influencing the economic improvement in the area to be even better. In addition, Doloksanggul is also one of the areas located in Lake Toba region and included in Toba Caldera which is currently much in the attention by the central government, in

*Corresponding author at: Department of Architecture, Faculty of Engineering, Universitas Sumatera Utara,

Jalan Perpustakaan Gedung J07, Medan 20155, Indonesia

E-mail address: nurlisa.ginting@gmail.com 
addition to Doloksanggul, there are seven more districts one of the calderas Toba. Other potentials that support for the establishment of business hotels in Doloksanggul are many attractions that also located in the area, some of them relics - the remains of history that still exist today. Because it is an area in the Toba Caldera region that protected its naturalness, the theme is Sustainable Architecture as one of the efforts in protecting nature conservation and respond well to the surrounding environment [1]. The topic of designing this business hotel as well as a reference that is expected to give a good influence for the natural state around for the future - the future.

\section{Literature Review}

\subsection{Object Description}

The main of designing is Doloksanggul Business Hotel with the essence of Sustainable Architecture which aims to accommodate business activities for occupation in Doloksanggul which is expected to support the economic improvement in this area. Business activities are mainly for business people who stay with a variety of activities in the area and facilitate important meetings and good lodging for visitors and business people in the area Doloksanggul. As a protected area of nature sustainability the designer takes the theme of sustainable buildings that serve as an effort to support the preservation of due, and respond to the culture that is still alive today is Toba culture.This designer will design the hotel building form by Bolon house (Batak Toba house).

\subsection{Location and Site}

The site is located in Dolok sanggul, Kab. Humbang hasundutan with an area of $2502.71 \mathrm{~km}$, with has 10 districts, one kelurahan with 143 villages. Located in the highland with cold air. In details, is on the Sidikalang - Medan street about $600 \mathrm{~m}$ from the city center. The site area is $+/$ 2.4 Ha with vacant land (Figure 1). 


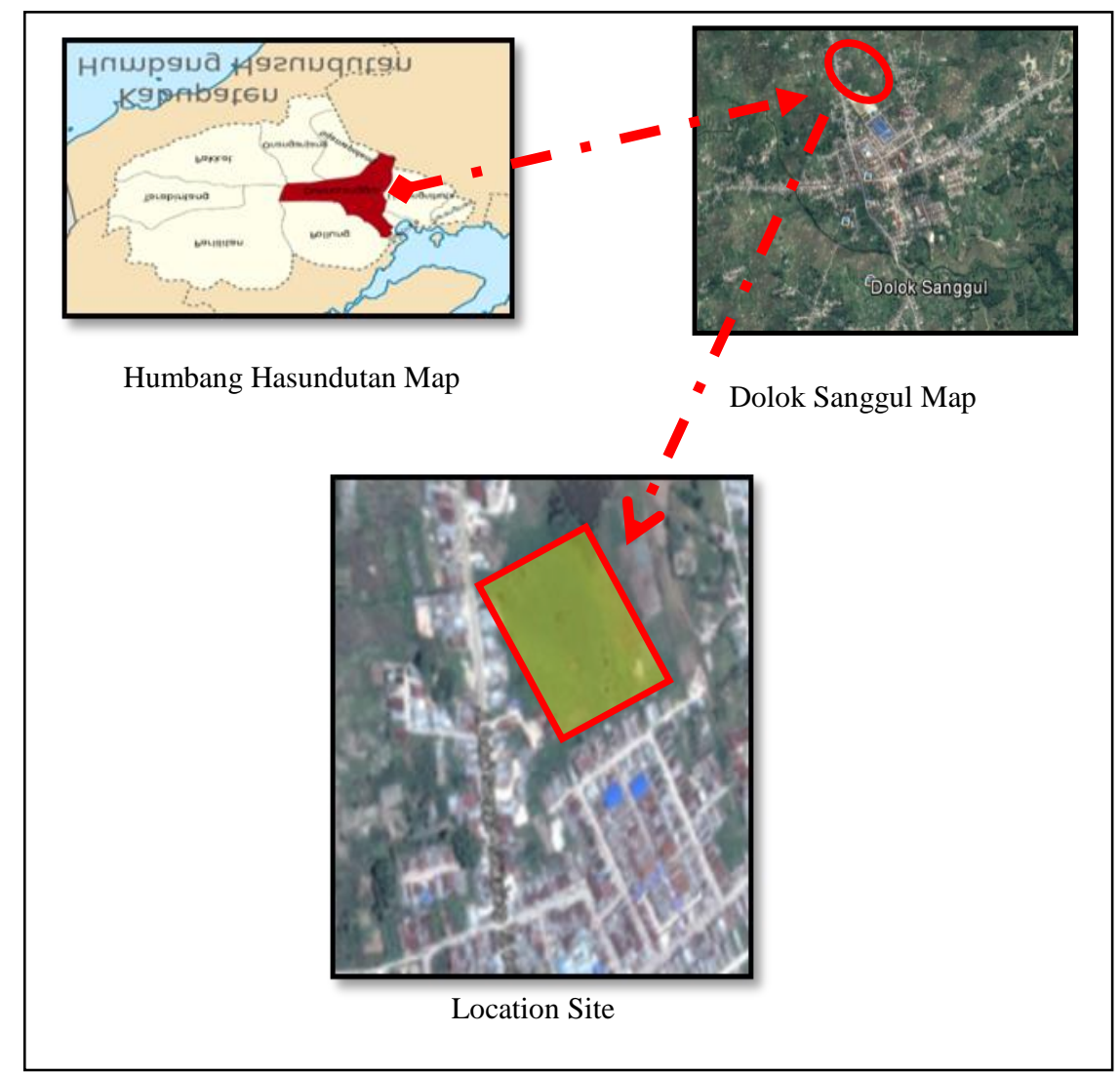

Figure 1. Location Site Dolok Sanggul

(Source: Google Earth)

\subsection{Theme Studies}

As one of the most important processes as well as the core in designing, the theme in the design must be a means in the direction of the process of designing objects Because it is the basis in designing. With the theme is also a distinctive feature of an object that distinguishes it from other objects that have the same function. The design idea is inseparable from the analysis and background of the designing tread. The use of sustainable concepts in architecture has been very often we meet at this time, this theme has a very wide scope such as green architecture too, ecology architecture and so forth. Todays with the global warming, of course, the sustainable concept is very familiar in the encounter in this situation [3].

Vertical vegetation that we often encounter in modern times is applied to the high buildings as one effort in maintaining the balance of nature in order not to affect the global warming, also maintain the quality of space, vertical vegetation concept is one of the Green Architecture concepts that refer On sustainable design (Figure 2 ). 


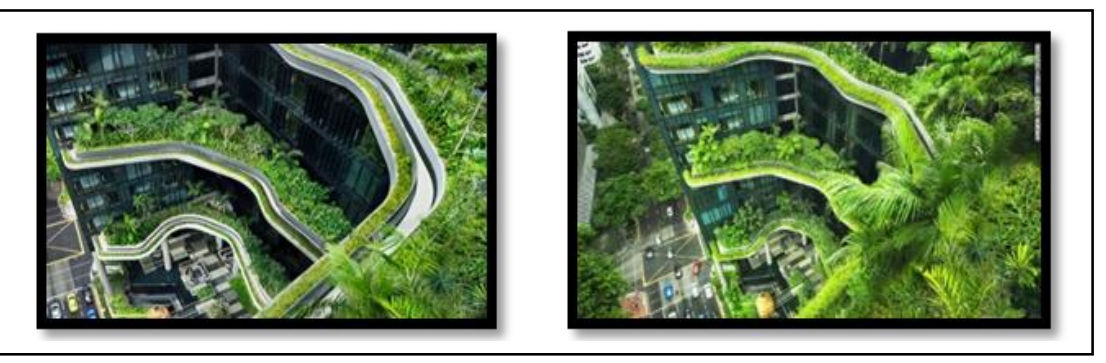

Figure 2. The Parkroyal building

(Source: pratiwinurrahmaddi.blogspot.co.id, 2016)

\section{Methodology}

\subsection{Method of collecting data}

The data collected the form of primary and secondary data. Primary data is collected data from through field surveys (conducting field observations to obtain site data). Secondary data is collected data from through comparative study of literature (do the comparative studies of objects and similar design themes also conducting studies with sourced from various literature both print media and electronic media).

\subsection{Method of data analysis}

The results of data that has been collected and then done the analysis, so that the best analysis results will be forwarded to the process of synthesis or pouring the concept idea into the design. Data analysis performed on the two types of data collection applied: Analysis of field data / site (Analysis of various tread elements is site size and pattern, site boundary and view, site topography, climatological conditions, hydrological, vegetation conditions and outer space elements, and Condition of facilities on the environment) and comparative study data analysis literature study (Comparative study analysis is expected to provide deeper insights and knowledge as a reference in designing object functions, space requirements and spatial patterns, and building facades and Decorative elements in buildings). The results of data analysis poured into the concept idea in designing. The transformation process pays attention to 3 main factors: processed object typology, processed tread, and operation of the design theme.

\section{Result and Discussion}

\subsection{Facilities Program}

Based on the analysis that has done one of them is the observation of activities, it can specify various that provided as the fulfillment of the needs of the user. Divided into several facility : Main of amenities, namely: Standard Room,(Standard A1, A2; S and B) and Suite Room, Ballroom, Meeting Room; Supporting Facilities namely: Restaurant (outdoor restaurant), Coffee shop, Lobby, Swimming pool, parking area; and Facilities managers,namely: The management office, Special room for hotel security, Security post and so on. 


\subsection{Analysis Site}

The site is located in a cold air with temperatures ranging from $22^{\circ} \mathrm{C}$. Site Area: $+/-2.4 \mathrm{Ha}$, has green converge $30 \%$ and building converge $60 \%$ with the existent state is empty Land. The middle-class hotels three stars and this Project Status is Fictitious ( Presidential Regulation No. 81 of 2014).

\subsection{The Concept of Outer Space}

The Main Building Hotell There are several public areas, semi-public and private on buildings such as the lobby, lunch, coffee shop (public); Ballroom and meeting room (semi-public) and front office, room unit, control room and the management area (private). Hotel Parking Area There is a 4-wheeler parking area (car and bus) as well as 2-wheeled parking (Motorbike). Swimming Pool It is a hotel support facility (Figure 3).

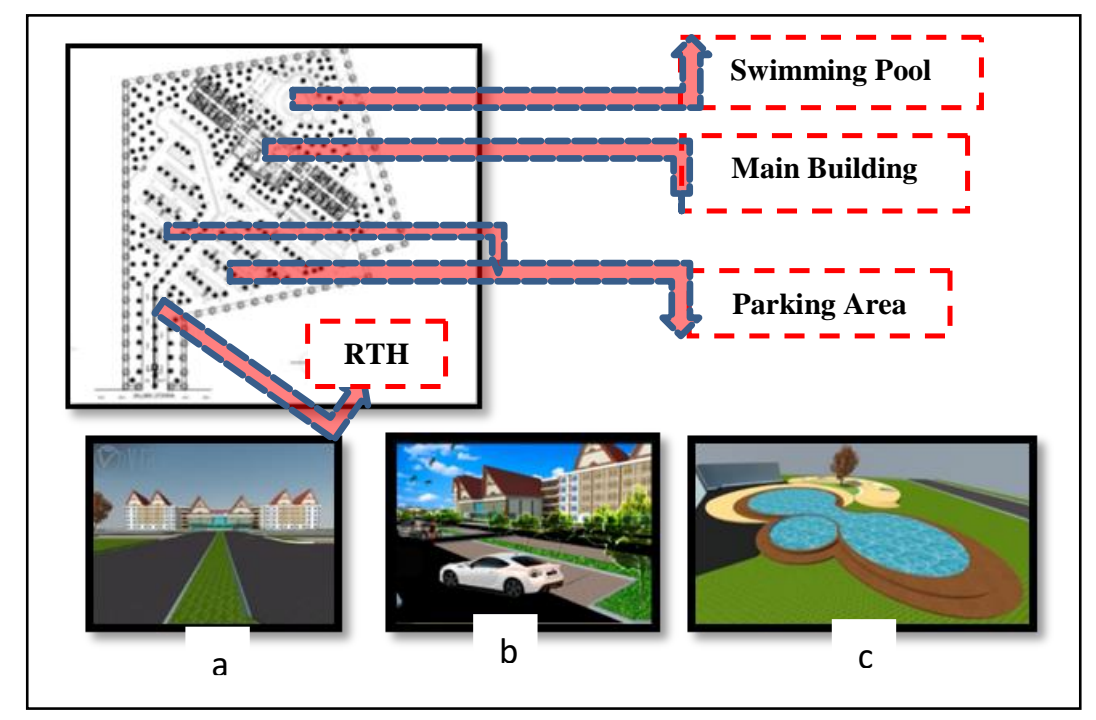

Figure 3. (a) The Main Building Hotell, (b) Hotel Parking Area, (c) Swimming Pool

\subsection{Circulation Concept}

Circulation in the site has been two areas: public area (main entrance) and service area. The Public area is in front of the main street hotel and service area hotel in the later building. For main entrance through the Dolok Sanggul - Sidikalang street and the exit is also the main road (two-way circulation). The parking area for the guest hotel, visitors, and employees. The service area has a certain exit of the business hotel (Figure 4). 


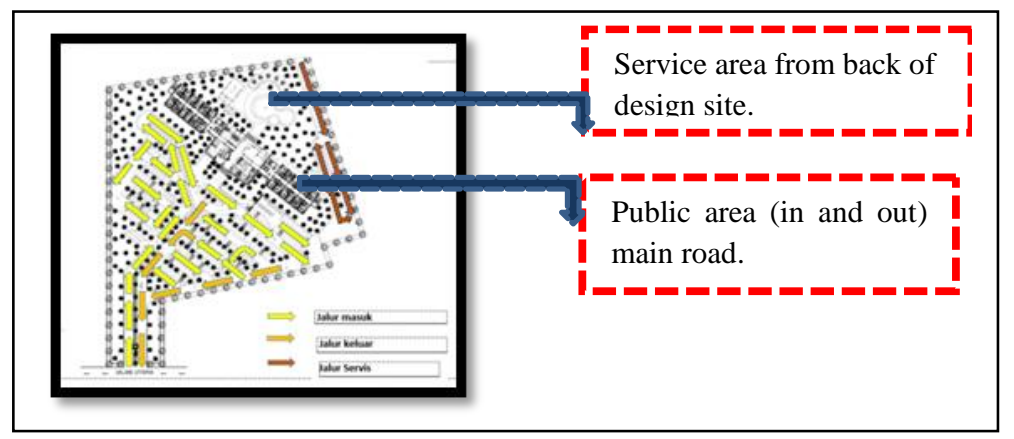

Figure 4. Circulation

\subsection{The Concept of Mass Composition}

As one of the efforts to respond the surrounding of environment famous for Batak Toba culture, then the transformed form is Bolon house. Bolon House has a high roof and curved above it, but for the hotel building itself, the roof is in straightening so it looks more good and interesting. (Figure 5). The final formation of this hotel building transforms directly from the quarter of a custom house Batak Toba which is the characteristic of the area where the location designed; this effort was well done as the respond this place. The building itself saves the use of the water, electricity, and used natural lighting. (Figure 6). There is vertical vegetation in the buildings as an effort to increase the ecological value and keep the building fresh in it (Figure 7).

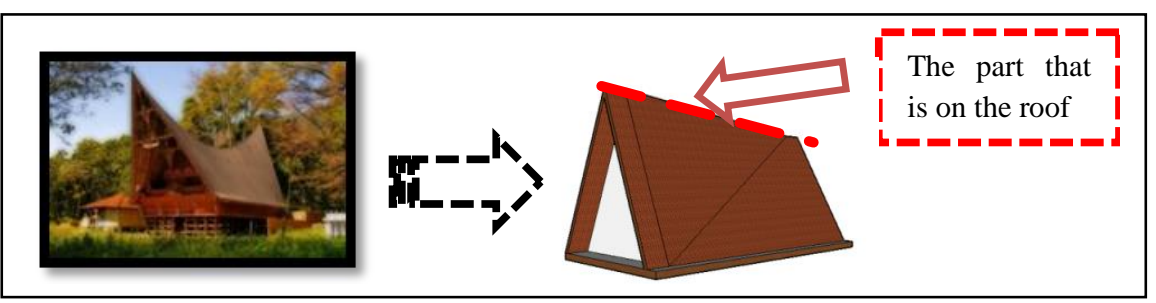

Figure 5. Roof Transformation

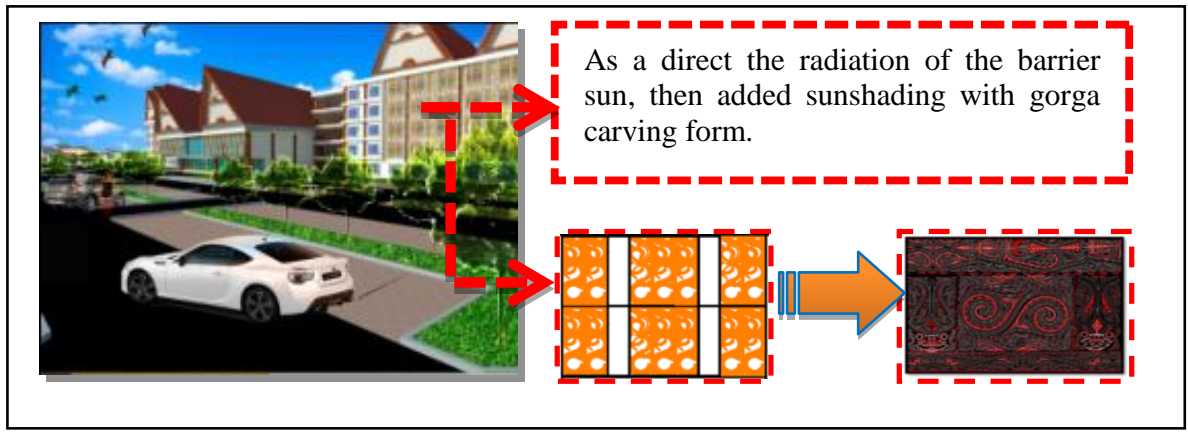

Figure 6. Sun shading carved in the shape of Gorga 


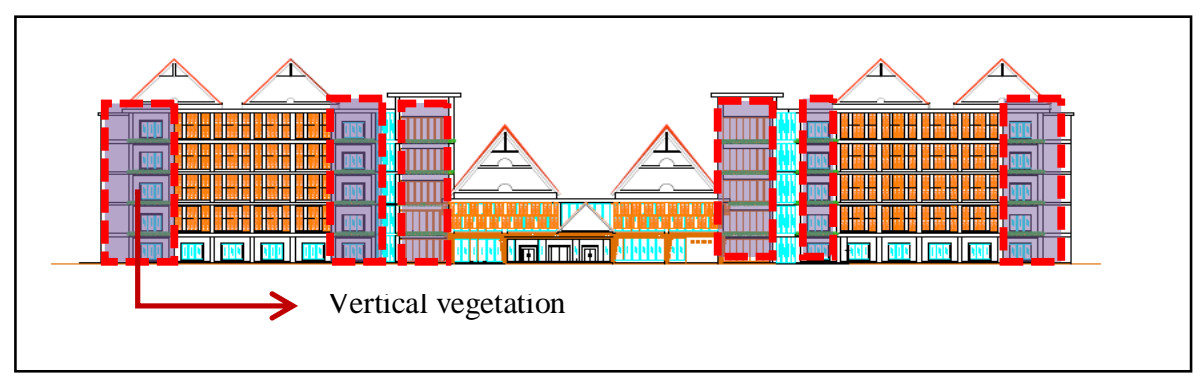

Figure 7. vertical vegetation

\subsection{The Utility System Concept}

Clean Water the building produces its own water from the rainwater reservoir and on though in the Rain Water Treatment System (SPAH) after the process will be reused. By using SPAH then rainwater will be processed before use in daily necessities in the building. In this case, is saying as the efficiency of used water (Figure 8). The concept of Gross Water Treatment System (waste) with Biofilter on sewage treatment systems and building wastes using water treatment with an aerobic-anaerobic biofilter ( Figure 9).

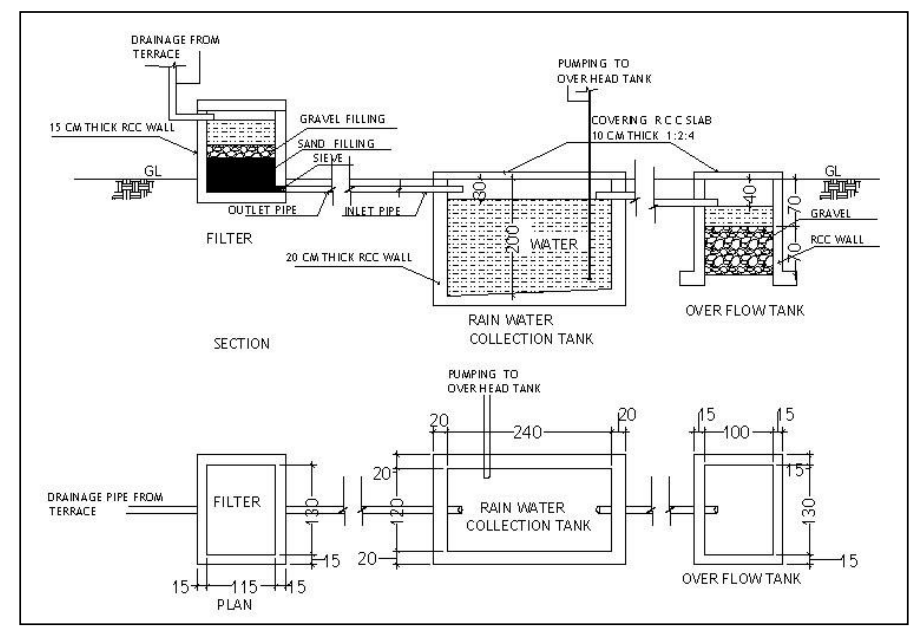

Figure 8. Schematic rainwater utility (Source:google.com)

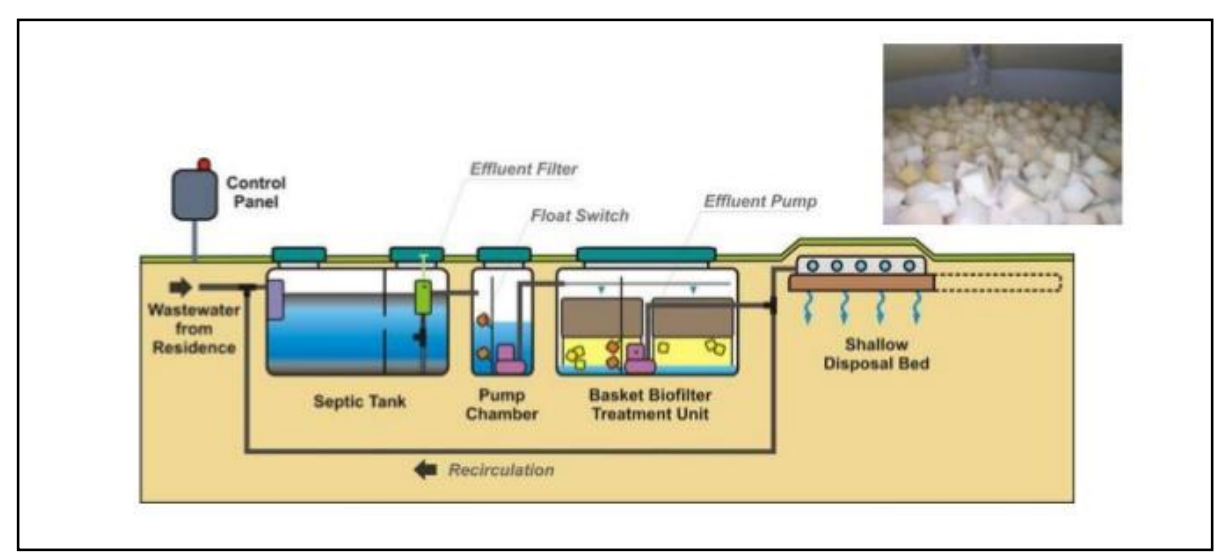

Figure 9. Water treatment with biofilter (Source: Gordon Balch's presentation, 2015) 
The concept of solid waste management system in buildings is divided into 3 channels from the building that is occupancy and public area in the building. Schematically can be described as follows (Figure 10).

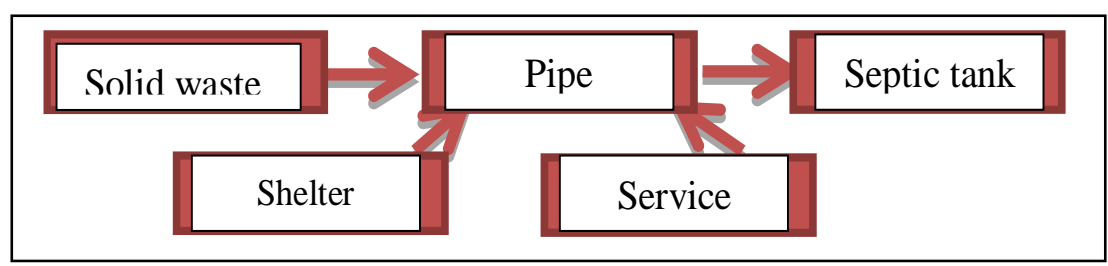

Figure 10. Solid waste system

\section{Conclusion}

Dolok Sanggul Kab. Humbang Hasundutan is one of the regencies located in the outskirts of Lake Toba and belongs to Toba Caldera, besides being a protected area, it is also a region that has many historical relics, as well as many attractions in it. Area of design land +/- 2.4 Ha with the situation of the site is empty and surrounded by green open space, located is near from downtown of Doloksanggul with a distance of $+/-600 \mathrm{~m}$ from the city center. The theme taken in the design is Sustainable Architecture which one of the designer's efforts in preserving nature and the condition around of the area, as well as other reference to appreciate the culture that is still very much alive in the daily life of the surrounding community.

\section{Acknowledgment}

This research is part of the requirement to obtain a bachelor's degree in Architecture Department, Universitas Sumatera Utara.

\section{REFERENCES}

[1] Y. Iskandar Putra. Perencanaan Dengan Konsep Sustainable Building. 2006.

[2] P. Rahmaddi. Tugas Arsitektur Lingkungan I. (online) http://pratiwinurrahmaddi.blogspot.co.id/2016/10/tugas-arsitektur-lingkungan1.html?view=classic, di akses tanggal 2017-04-26. 2016.

[3] M. M. Sudarwani. Penerapan Green Architecture dan Green Building sebagai upaya pencapaian sustainable Architecture. Dinamika Sains, 2012, 10(24).

[4] E. P. Tanjung. Hotel Bisnis Kualanamu. 2012. 